\title{
CONTRACEPTIVE EFFECT OF NEEM SEED OIL AND ITS ACTIVE FRACTIONS ON FEMALE ALBINO RABBITS
}

\author{
VIJEYATA VYAS ${ }^{1 *}$, ASHOK PUROHIT ${ }^{2}$
}

${ }^{1}$ Department of Zoology, Mahila P.G.College, Jodhpur, Rajasthan, India. ${ }^{2}$ Department of Zoology, Jai Narain Vyas University, Jodhpur, Rajasthan, India. Email: vijetapaniya456@gmail.com/purohit1411@rediffmail.com.

Received: 28 June 2018, Revised and Accepted: 13 August 2018

\section{ABSTRACT}

Objective: In the present investigation, contraceptive efficacy of neem seed oil and its fractions have been examined in female albino rabbits to find out their contraceptive potential.

Methods: The experimental protocol was designed for intact control, Neem seed oil alone and its six active fractions in eight groups for 30 days. The estimation of serum biochemistry, histometry of reproductive organs, and hematological parameters were done.

Results: Oral administration of Neem seed oil alone and its Fraction IV and V causes significant reduction in weight of ovary and uterus which reflects antiestrogenic function of plant material. Significant increase in serum cholesterol and phospholipid in Neem seed oil alone and its Fraction IV and V-treated groups reflects that they may affect the intraovarian estrogen level either by inhibiting the ovarian cell function or by inhibiting folliclestimulating hormone and luteinizing hormone secretion through hypothalamus-hypophysis axis and impaired estrogen synthesis.

Conclusion: From the ongoing work, it can be concluded that Neem seed oil alone and its Fraction IV and V cause functional sterility in female albino rabbits without causing any side effect on general metabolism.

Keywords: Contraceptive, Histometry, Intraovarian, Hypothalamus.

(C) 2018 The Authors. Published by Innovare Academic Sciences Pvt Ltd. This is an open access article under the CC BY license (http://creativecommons. org/licenses/by/4. 0/) DOI: http://dx.doi.org/10.22159/ajpcr.2018.v11i12.28188

\section{INTRODUCTION}

Today, alarming rate of population growth is one of the most imminent hurdles of country's development if the population is not controlled or checked it will lead to several problems [1]. To control the population, it is necessary that there will be availability of safe contraceptive. Natural products are a significant source of synthetic and traditional herbal medicine and are still the primary health-care system $[2,3]$. Azadirachta indica commonly known as Neem tree has also been called as multipurpose tree [4] because it's all parts have been used in various medicinal preparations. $>135$ compounds have been isolated from different parts of Neem [5,6]. It has been reported to possess antiviral, antifungal, antibacterial, and anti-inflammatory properties. Similarly, antidiabetic and antiatherosclerotic effect of Neem plant was also reported [7]. Neem seed oil is known to have antifertility and antiovulatory effect [8]. It has also reported that Neem seed oil inhibits folliculogenesis in albino rabbits and also the significant change in the levels of associated reproductive hormones $[9,10]$. The present study was undertaken to evaluate the effect of six active fractions of Neem seed oil and their contraceptive efficacy in female albino rabbits for developing antifertility agent from the indigenous plant sources.

\section{METHODS}

\section{Extraction of plant material}

The ripe fruit of Neem was collected in an around new campus of Jai Narain Vyas University, Jodhpur, and identification was done by the Department of Botany, Jai Narain Vyas University, Jodhpur. After collection, they were cleaned, depulped, and dried in bright sunlight for about 10-12 h and decorticated mechanically by double roller miles. The crushed kernels were initially blended with the hexane. The crushed material was packed into cellulose thimble and placed in extractor. Hexane was recovered by distillation and the residue left after distillation was collected and to prevent oxidation Neem seed oil was stored under refrigeration.

\section{Fractionation}

$50 \mathrm{~g}$ of Neem seed oil was chromatographed over deactivated silica gel in glass column and six major fractions were eluted with EtOH/hexane in six different proportions (Table 1).

\section{Experimental animals}

Healthy adult female albino rabbits were housed in well-lighted airconditioned room in metallic wire gauge cages under controlled environment with $24 \mathrm{~h}$ light/dark cycle. All the rabbits were fed on standard rabbit chow supplied by Hindustan Lever Ltd., India. The food was supplemented with green leafy and seasonal vegetables and water ad libitum.

\section{Experimentation}

Mature regular cyclic female albino rabbits were divided into eight groups of three animals each as given in Table 2. For this experiment, weight and age of animal were $1.25-1.75 \mathrm{~kg}$ and $10-12$ months, respectively, and the route of drug administration was orally. The experimental protocol was approved by the Institutional Animal Ethical committee.

\section{Serum biochemistry}

At the end of experiments, all rabbits were sacrificed under prolonged anesthesia and blood were collected through direct cardiac puncture. Collected blood was stored in EDTA vials at $20^{\circ} \mathrm{c}$, and hematological parameters were examined through standard method $[11,12]$ and serum was separated and stored $\mathrm{at}-20^{\circ} \mathrm{C}$ and analyzed for different parameters by standard methods such as cholesterol [13] and phospholipids [14].

\section{Histrometry}

Uterine epithelial nuclear diameter and vaginal epithelial nuclear diameter were traced at $\times 800$ with camera lucida. The epithelial cell height of uterus and vagina was also traced at $\times 360$. Follicular types such as primary secondary and mature were calculated by observing stained sections of ovary. 
Statistical analysis

All the values of body/organ weights, biochemical estimation, and histometry and follicular numbers were expressed in terms of mean value \pm standard error. The different groups were compared among each other using Student's t-test [15].

\section{RESULTS}

\section{Morphological study}

Body weight (Figs. 1-2)

Non-significant changes occurred in body weight of experimental animals of all treatment groups. Administration of Neem seed oil (Group 2) and its chromatographic Fraction IV and V (Group 6-7)

Table 1: Weight of eluted six major fractions

\begin{tabular}{llll}
\hline Fraction & $\begin{array}{l}\text { Amount of } \\
\text { EtOH (\%) }\end{array}$ & $\begin{array}{l}\text { Amount of } \\
\text { hexane (\%) }\end{array}$ & $\begin{array}{l}\text { Weight of the } \\
\text { fraction (g) }\end{array}$ \\
\hline I & 0 & 100 & 2.232 \\
II & 7 & 93 & 2.438 \\
III & 20 & 80 & 4.680 \\
IV & 30 & 70 & 7.128 \\
V & 80 & 20 & 2.844 \\
VI & 100 & 0 & 1.44 \\
\hline
\end{tabular}

Table 2: Dose determination of experimental animals

\begin{tabular}{lll}
\hline Experimental Groups & $\begin{array}{l}\text { Dose in mg/1 kg } \\
\text { body Wt. }\end{array}$ & Autopsy schedule \\
\hline Group 1, (olive oil) & $1 \mathrm{ml}$ & On $31^{\text {st }}$ day \\
Group 2, (neem seed oil) & $500 \mathrm{mg}$ & On $31^{\text {st }}$ day \\
Group 3, (Fraction I) & $9 \mathrm{mg}$ & On $31^{\text {st }}$ day \\
Group 4, (Fraction II) & $10 \mathrm{mg}$ & On $31^{\text {st }}$ day \\
Group 5, (Fraction III) & $19 \mathrm{mg}$ & On $31^{\text {st }}$ day \\
Group 6, (Fraction IV) & $28 \mathrm{mg}$ & On $31^{\text {st }}$ day \\
Group 7, (Fraction V) & $10 \mathrm{mg}$ & On $31^{\text {st }}$ day \\
Group 8, (Fraction VI) & $7 \mathrm{mg}$ & On $31^{\text {st }}$ day \\
\hline
\end{tabular}

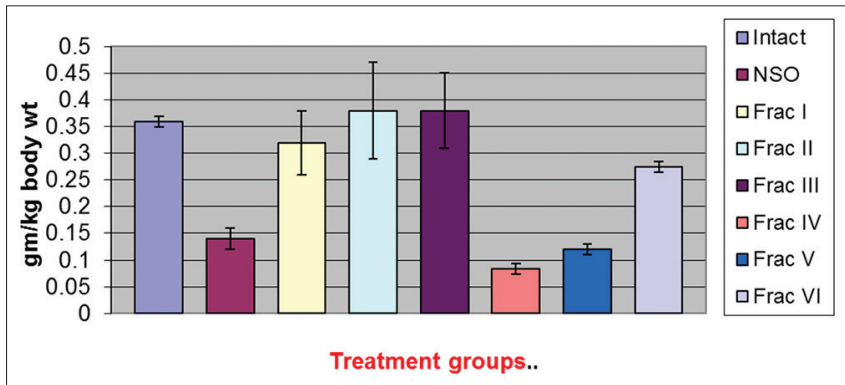

Fig. 1: Graphical representation of changes in the weights of ovary (mean of five values \pm standard error of the mean) of neem seed oil alone or various fractions treated intact female rabbits

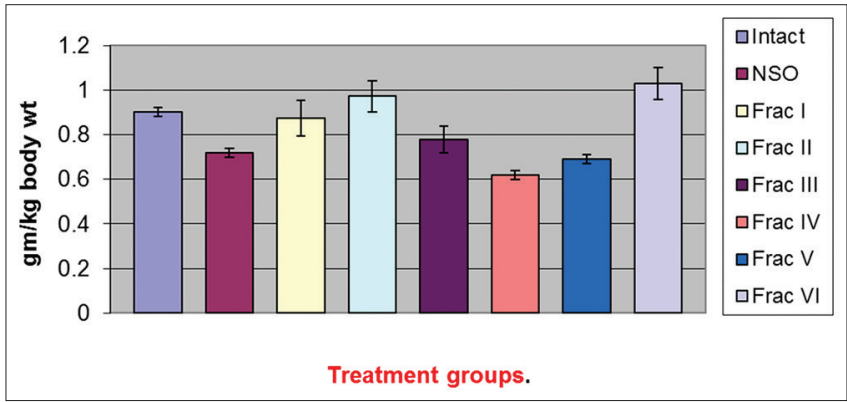

Fig. 2: Graphical representation of changes in the weights of uterus (mean of five values \pm standard error of the mean) of Neem seed oil alone or various fractions treated intact female rabbits brought about significant reduction in the weight of ovary and uterus in relation to control.

Histrometry (Figs. 3-5)

Histrometry of uterus wall including epithelial cell height and its nuclear diameter shows the shrinkage in the Neem seed oil and its Fraction IV and Fraction V. Similarly, vaginal epithelial cell height and its nuclear diameter also show reduction in Neem seed oil alone (Group 2) and its Fractions IV and V (Group 6-7) treatment groups. The number of mature follicles reduces drastically.

\section{Hematology}

The hematological parameters such as blood sugar, red blood cells, white blood cells, and hemoglobin concentration of vehicle-treated control (Group 1), neem seed oil (Group 2), Fraction I (Group 3), Fraction 2 (Group 4), Fraction III (Group 5), Fraction IV (Group 6), Fraction V (Group 7), and Fraction VI (Group 8) values were all found in normal range in all treatment groups.

\section{Serum biochemistry (Figs. 6 and 7)}

The serum biochemistry such as cholesterol, phospholipids of vehicletreated control, and all other experimented groups was represented in Fig. 6 and 7. The concentration of cholesterol when estimated in Neem seed oil (Group 2), Fraction IV (Group 6), and Fraction V (Group 7)-treated rabbits increased, which was statistically significant ( $p=0.001$ ) while as in Fraction I, II, III, and VI treated shows no significant changes. Phospholipids concentration also increases in Neem seed oil (Group 2) and Fraction IV and V (Group 6-7)-treated intact rabbits.

\section{DISCUSSION}

A reduction in the weight of ovary and uterus suggests antiestrogenic nature of Neem seed oil alone and its Fraction IV and V. Isolated fraction of neem seed oil was found to be more effective in comparison

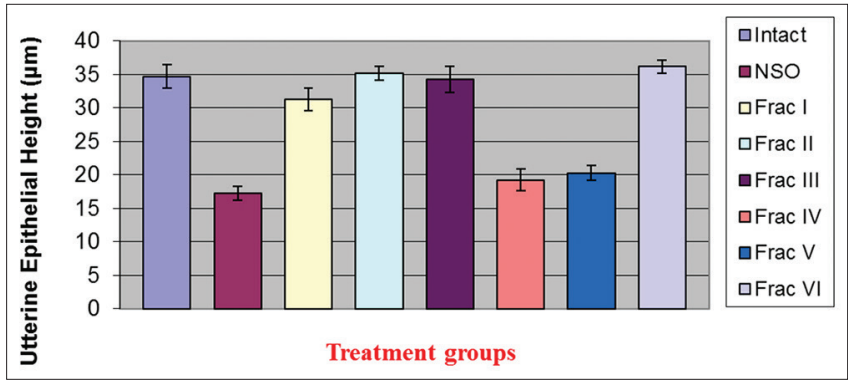

Fig. 3: Graphical representation of changes in the heights of uterus epithelial (mean of five values \pm standard error of the mean) of neem seed oil alone or various fractions treated intact female rabbits

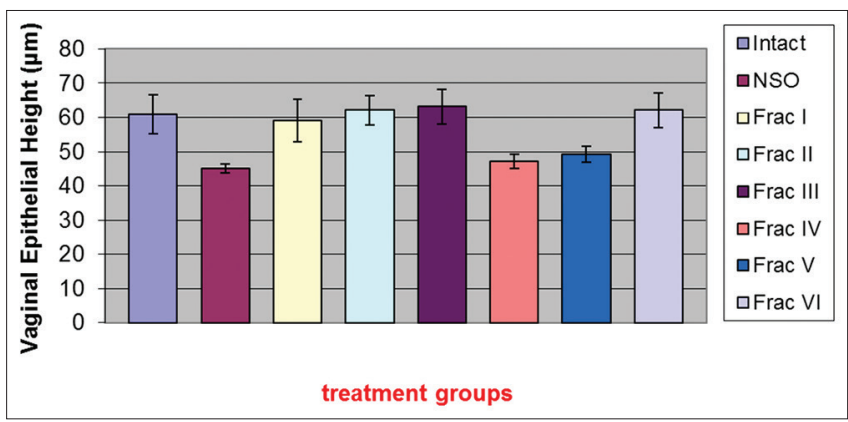

Fig. 4: Graphical representation of changes in the vaginal epithelial height (mean of five values \pm Standard error of the mean) of neem seed oil alone or various fractions treated intact female rabbits 


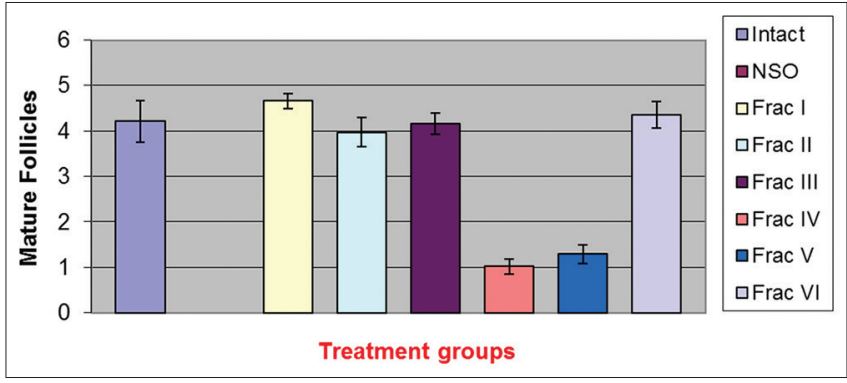

Fig. 5: Graphical representation of changes in the mature follicles number (mean of five values \pm standard error of the mean) of neem seed oil alone or various fractions treated intact female rabbits

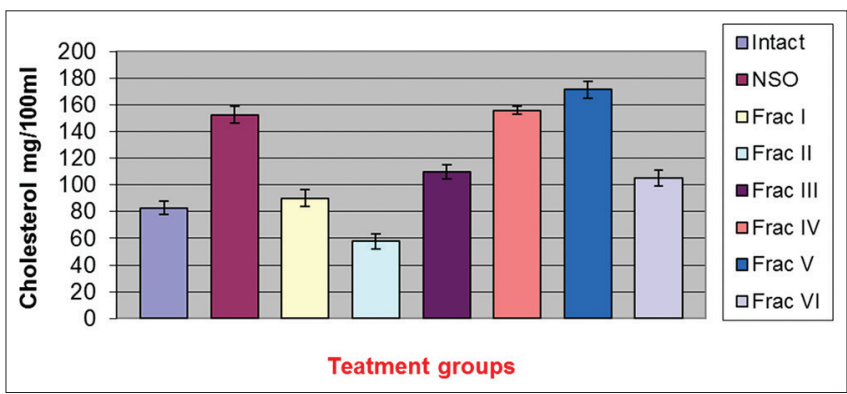

Fig. 6: Graphical representation of changes in the concentration of serum cholesterol (mean of five values \pm standard error of the mean) of neem seed oil alone or various fractions treated intact female rabbits

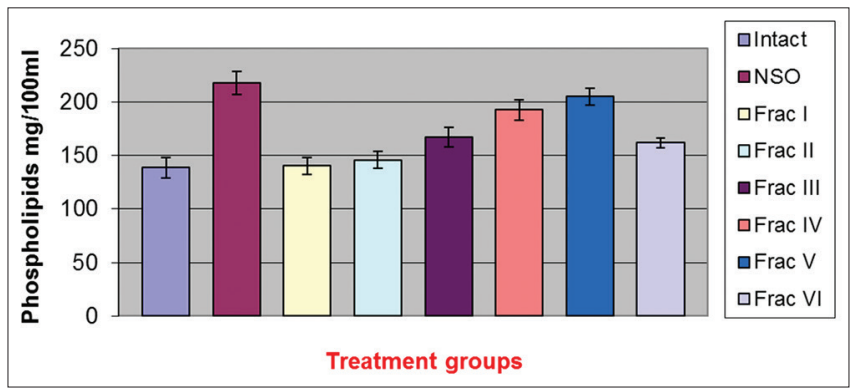

Fig. 7: Graphical representation of changes in the concentration of serum phospholipid (mean of five values \pm standard error of the mean) of neem seed oil alone or various fractions treated intact female rabbits

to Neem seed oil alone and this is due to reduced estrogen level. Histromerty of uterus and vagina shows significant reduction in cell height and nuclear diameter in the Neem seed oil alone and its Fraction IV and V. As the functional status of these organs is mainly dependent on estrogen $[16,17]$, whereas in other groups no significant changes were observed. It indicates that Neem seed oil and its Fraction IV and V may have antiestrogenic nature $[18,19]$. The essential prerequisite in the process of ovulation is complex sequence of hormonal events there includes timed preovulatory rise of threshold levels of estradiol followed by an ovulatory luteinizing hormone (LH) peak and subsequent ride in progesterone [20-22]. During the initial development, the ovarian follicles cells produce estrogen, and during the latter stage under the influence of LH, they produce progesterone $[23,24]$. Since the maturation of follicles has been affected by Neem seed oil and its Fraction IV and Fraction V. In the all above three treatment groups, the number of follicles reduces drastically which reflects inhibitory function of neem seed oil and its Fraction IV and V. Similarly, the increased level of serum cholesterol may show the antiestrogenic nature of plant material because cholesterol is an important precursor in synthesis of steroid hormones [25-28]. The specific function of cholesterol in the ovary is to act as precursor molecule for synthesis of estrogen [29] so the increased level is thus due to non-utilization of cholesterol due to inhibitory ovary function so it is confirmed that Neem seed oil alone and its Fraction IV and V may affect the intraovarian estrogen level either by inhibiting the ovarian cell function or by inhibiting follicle-stimulating hormone and LH secretion through hypothalamus-hypophysis axis, and impaired estrogen synthesis has been achieved resulting infertility. Hematology and serum study shows that Neem seed oil and its all fractions have no toxic effect on general metabolism.

\section{CONCLUSION}

From the ongoing work, it can be concluded that neem seed oil alone and its Fraction IV and V cause functional sterility in female albino rabbits without causing any side effect on general metabolism.

\section{ACKNOWLEDGMENT}

We would like to acknowledge Head, Department of Zoology, Jai Narain Vyas University, Jodhpur, and Rajasthan, for providing all facilities.

\section{AUTHORS' CONTRIBUTIONS}

The complete research work was suggested and mentored by Prof. Ashok Purohit. All the experimental works were performed by Vijeyata Vyas. Author drafted and approved the final manuscript.

\section{CONFLICTS OF INTEREST}

The authors declare that they have no conflicts of interest.

\section{REFERENCES}

1. Sailani MR, Moeini H. Effect of Ruta graveolens and Cannabis sativa alchoholic extract on spermatogenesis in the adult wistar rats. Indian J Urol 2008;23:257-60.

2. Ponugoti M. A pharmalogical and toxiological reviews of Lawsonia inermis. Int J Pharm Sci Res 2018;9:902-15.

3. Oyedeji KO, Bolarinwa AF. Evalution of antifertility and teratogenic effects of crude extract of Portulaca oleracea in female albino rats. Asian J Pharm Clin Res 2013;6:217-20.

4. Shah SK, Hade DJ, Chouksey R. Evalute the antifertility potential of Ficus racemosa linn bark on female wistar rats. Asian J Pharm Clin Res 2016;9:322-6

5. Ahmed SA, Grainage M. Potential of neem tree for pest control and rural development. Econ Bot 1986;40:201-8.

6. Zade V, Wikhe M, Dabhadkar D, Dawada S, Patil U. Antifertility efficacy of Cannabis sativa leaves on female albino rats. Int J Sci 2013;2:107-17.

7. Siddique BS, Siddique S, Faizi S, Ghiasuddin. Constituent of Azardichta indica isolation and structure elucidation of a new antibacterial teteranortriterpenoid and a new proto limnoid, Naheedin. J Nat Prod 1992;55:303-10.

8. Lal R, Sukharanarayan A, Mathur VS, Sharma PL. Antifertility effect of Neem oil in female albino rats by intra vaginal and oral routes. Ind $\mathbf{J}$ Med Res 1986;83:82-92.

9. Purohit A. Antifertility efficacy of neembark (Azadirachta indica a. juss) in male rats Anc Sci Life 1999;19:21-4

10. Reddy MK, Kokate CK, Chari N. Antiovulatory effect of different crude drug combinations in female albino rats. Anc Sci Life 1984;4:132-4.

11. Roop JK, Dhaliwal PK, Guraya SS. Extract of Azadirachta indica and Melia azedarach seed inhibits folliculogenesis in albino rats. Braz J Med Biol Res 2005;38:943-7.

12. Montaserti A, Pourheydar M, Khazaei M, Ghorbani M. Antifertility effect of Phyaslis alkengi alchoholic extract in female rats. Iran J Reprod Med 2006;5:13-6.

13. Zaltkis A, Zak B, Boyle AJ. A new method for the direct determination of serum cholesterol. J Lab Clin Med 1953;41:486-92.

14. Zilversmit DB, Davis AK. Microdetermination of plasma phospholipids by trichloroacetic acid precipitation. J Lab Clin 1950;35:155-60

15. Ipstein J, Poly F. In Banchroft's Introduction to Biostatistics. $2^{\text {nd }}$ ed. New York: Harper International; 1950. p. 44-64.

16. Yadav R, Jain GC. Antifertility effect and hormonal profile of petroleum 
ether extract of seeds of Cassia fistula in female rats. Int J Pharm Tech Res 2009;1:438-44.

17. Nayak HB, Ramesh L, Londonkar RL, Andumesh MK. Evaluation of Portulaca oleracea 1 . for anti-fertility effect in female albino rats. Int $\mathbf{J}$ Pharm Pharm Sci 2014;6:86-9.

18. Nivsarkar M, Patel M, Padh H, Bapu C, Shrivastava N. Blastocyst implantation failure in mice due to non-respective endometrium endometrial alterations by Hibiscus rosa-sinensis leaf. Contraception 2005;71:227-30

19. Vessal M, Rasti M, Rooshesh F. Modulation of the pituitary and basaedial hypothalamic lysyl-aminopeptidase activities beta-estradiol and/or anageous extract of Physalis alkekgni fruits. Comp Biochem Physiol Mol Biol 1996;115:267-71.

20. Barrayan J, Brotons JA, Acien P. Experimently induced endometrioisis in rats: Effect on fertility and the effect of pregancy and lactation on the ectopic endometrial tissue. Fertil Steril 1992;58:1215-9.

21. Shaikh MA, Naqvi SN, Khani ZA. Effect of neem oil on the structure and function of the mature female albino rat ovaries. Einstein 2009; 7:28-34.

22. Das B, Das A, Talukdar B, Choudhary MD. A few traditional medicinal plants used as antifertility agents by ethenic people of Tripura, India. Int J Pharm Pharm Sci 2014;6:47-53.
23. Pala AK, Biswass K, Goswamib S, Kabir SN. Effect of pelvic endometrial implants on overall reproductive function of female rats. Biol Reprod 1999;60:954-8.

24. Badami S, Aneesh R, Sarkar S, Satishkumar M, Suresh B, Rajan S. Antifertility activityof Derris berevipes variety coriacea. J Ethanopharmacol 2003;84:99-104.

25. Vaidya P, Padmashali S, Vagdevi MM, Sathyanarayana ND. Antifertility effect of the plant Balanites roxburghi (Balanitaceae) in female rats. Ind J Pharm Sci 2000;3:347-51.

26. Kage DN, Malashetty VK, Seetharam YN, Suresh P, Patil SB. Effect of Ethanol Extract of whole plant of Trichosanthes cucumerina var. Cucumerina L. on gonadotropins, ovarian follicular kinetics and estrous cycle for screening of antifertility activity in albino rats. Int $\mathrm{J}$ Morphol 2009;27:173-82.

27. Ghosh A, Jana K, Pakhira BP. Anti-fertility effect of aqueousethanolic (1:1) extract of the fruit of Terminalia chebula: Rising approach towards herbal contraception. Asian Pac J Reprod 2015;4:201-7.

28. Purohit H, Vyas V, Ram H. Thar desert medicinal plants in relation to fertility regulation. Advance in medicinal plant research. Agrobios 2012;44:225-9.

29. Agarwal A, Allan JJ. Antifertility effects of herbs: Need for responsible reporting. J Ayur Integr Med 2010;1:129-31. 